\title{
RECORD OF Ostrea puelchana D'ORBIGNY, 1842 (BIVALVIA: OSTREIDAE), AS NEW EPIBIONT IN Eriphia gonagra (FABRICIUS, 1781) (CRUSTACEA: ERIPHIIDAE) FROM NORTHEASTERN BRAZIL
}

\author{
Registro de Ostrea puelchana d'Orbigny, 1842 \\ (Bivalvia: Ostreidae), como novo epibionte em Eriphia gonagra \\ (Fabricius, 1781) (Crustacea: Eriphiidae) para o Nordeste do Brasil \\ Flavio de Almeida Alves Júnior ${ }^{1}$, Débora Lucatelli ${ }^{2}$, Jonata Arruda Francisco ${ }^{3}$, \\ Gledson Fabiano de Araújo Ferreira ${ }^{4}$, Jesser Fidelis de Souza-Filho ${ }^{5}$
${ }^{1}$ Centro Universitário Brasileiro (Unibra), Universidade Federal de Pernambuco (UFPE), Museu de Oceanografia Prof. Petrônio Alves Coelho (MOUFPE), Laboratório de Carcinologia (LabCarcino), Recife, Pernambuco, Brasil. E-mail: bioflavio@hotmail.com
2 Universidade Federal de Pernambuco (UFPE), Museu de Oceanografia Prof. Petrônio Alves Coelho (Moufpe), Laboratório de Carcinologia (LabCarcino), Recife, Pernambuco, Brasil. E-mail: dla.lucatelli@gmail.com ${ }^{3}$ Centro Nacional de Pesquisa e Conservação da Biodiversidade Marinha do Nordeste (Cepene), Tamandaré, PE, Brasil. E-mail: jonatafrancisco@gmail.com
${ }^{4}$ Universidade de Pernambuco (UPE), Nazaré da Mata, Pernambuco, Brasil. E-mail: gledsonfabiano@gmail.com
${ }^{5}$ Universidade Federal de Pernambuco (UFPE), Museu de Oceanografia Prof. Petrônio Alves Coelho (Moufpe), Laboratório de Carcinologia (LabCarcino). Recife, Pernambuco, Brasil. E-mail: jesser.fidelis@ufpe.br

\begin{abstract}
In this paper, we describe the first association of the ostreid species Ostrea puelchana d'Orbigny, 1842, as new epibiont in Eriphia gonagra (Fabricius, 1781), with material collected in Northeastern Brazil. The specimens of E. gonagra were collected manually in November of 2020 during the low tide in the Barra de Catuama beach, State of Pernambuco. Among 10 specimens collected, only one adult male showed the presence of two commensal specimens of $O$. puelchana adhered in the epibranchial and antero-lateral regions of the basibiont (right side). The presence of the epibiont O. puelchana on the new host E. gonagra expands the range of the crustacean species potentially used as hosts by this oyster along the Brazilian coast.
\end{abstract}

Keywords: marine invertebrates, biological interactions, Pernambuco, commensalism, beachrocks.

Recebido em: 31/03/2021

Aprovado em: 30/06/2021

Publicado on-line em: 20/12/2021 


\section{RESUMO}

Neste artigo, nós descrevemos a primeira associação da espécie de ostreídeo Ostrea puelchana d'Orbigny, 1842, como novo epibionte em Eriphia gonagra (Fabricius, 1781), com material coletado no Nordeste do Brasil. O espécime de E. gonagra foi coletado manualmente em novembro de 2020 durante a maré baixa na praia de Barra de Catuama, no estado de Pernambuco. Entre os 10 espécimes coletados, apenas um macho adulto demonstrou a presença de dois espécimes comensais de $\mathrm{O}$. puelchana aderidos nas regiões epibranquial e anterolateral do basibionte (lado direito). A presença do epibionte O. puelchana como novo hospedeiro de E. gonagra expande a gama de espécies de crustáceos potencialmente utilizadas como hospedeiros dessa ostra ao longo da costa brasileira.

Palavras-chave: invertebrados marinhos, interações biológicas, Pernambuco, comensalismo, arenitos de praia.

Biological interactions between marine invertebrates are widely reported in the literature, with observations of intra- or inter-specific associations in different aspects as: symbiosis, parasitism, mutualism or commensalism (Hoffmeister \& Martin, 2003; Emparanza et al., 2011; Góngora-Gómez et al., 2015). For these associations, the body surface plays a crucial role as a hard substrate for the fixation of many invertebrate groups in a wider range of the marine hosts (Wahl, 2008).

In estuarine and marine zones, the mollusks can be observed in different lifestyles, being in free-living or occupying a wide range of substrates such as: mangrove roots, rocks, in anthropogenic areas (e.g. piers, ports, boats, ships), associated to marine litter (e.g. tires and pet bottle), or adhered to other invertebrates as: corals, sponges, polychaetes tubes, other mollusks and crustaceans, developing a wide plasticity of shapes for these occupations (O'Connor \& Newman, 2001; McDermott, 2006; Emparanza et al., 2011).

Bivalves of the family Ostreidae Rafinesque, 1815 are commonly found in coastal zones, occurring mostly in consolidated substrates or living as epibionts of invertebrates such as: sponges, corals, echinoderms and crustaceans (Amaral \& Simone, 2014; Ferreira-Jr.; Christo \& Abster, 2015; Hanke et al., 2015). Despite the great diversity of ostreids species in tropical areas, the genus Ostrea Linnaeus, 1758 is widely distributed in Americas as opportunistic commensal or symbionts, especially the species O. puelchana d'Orbigny, 1842, which is reported adhered in a wider range of invertebrate hosts (Rios, 2009; Lima et al., 2017).

Despite the wide distribution in coastal zones along the Americas, the crab species of Eriphia gonagra (Fabricius, 1781) (Eriphiidae MacLeay, 1838) is currently analyzed in many aspects as: taxonomy, ecologic and biologic aspects, reproductive traits or as bioindicators of anthropogenic impacts (Melo, 1996; Góes \& Fransozo, 2000; Andrade et al., 2014). However, the information of aspects as symbiosis or parasitism with other groups are scarce (e.g. with punctual cases of observation of E. gonagra with coastal barnacles, bryozoans and sponges) or nonexistent (Mantelatto \& Souza-Carey, 1998). Based on that, herein, we report the first association of the species O. puelchana as epibiont of E. gonagra with material collected in Northeastern Brazil.

A total of 10 specimens of E. gonagra were collected manually during the low tide in the Barra de Catuama beach (Figure 1), located on the north coast of Pernambuco $\left(7^{\circ} 33^{\prime}\right.$ 
$38^{\prime \prime}$ S; $35^{\circ} 0^{\prime} 9^{\prime \prime}$ W) in November of 2020, which the sampling was performed above the beachrocks (region influenced by the wave action and in biogenic substrate). The region of Barra de Catuama is formed by the influence of the estuary of the Itapessoca river giving rise to the coastal plain and the presence of beachrocks. This area is delimited by the megathermal climate with rainfall concentrated from March to August and a well-defined dry period (September to February), characterizing the As' climate (Hot Humid Tropical) (Köeppen, 1948).

Figure 1 - Location of the study area in Barra de Catuama beach, State of Pernambuco, Brazil

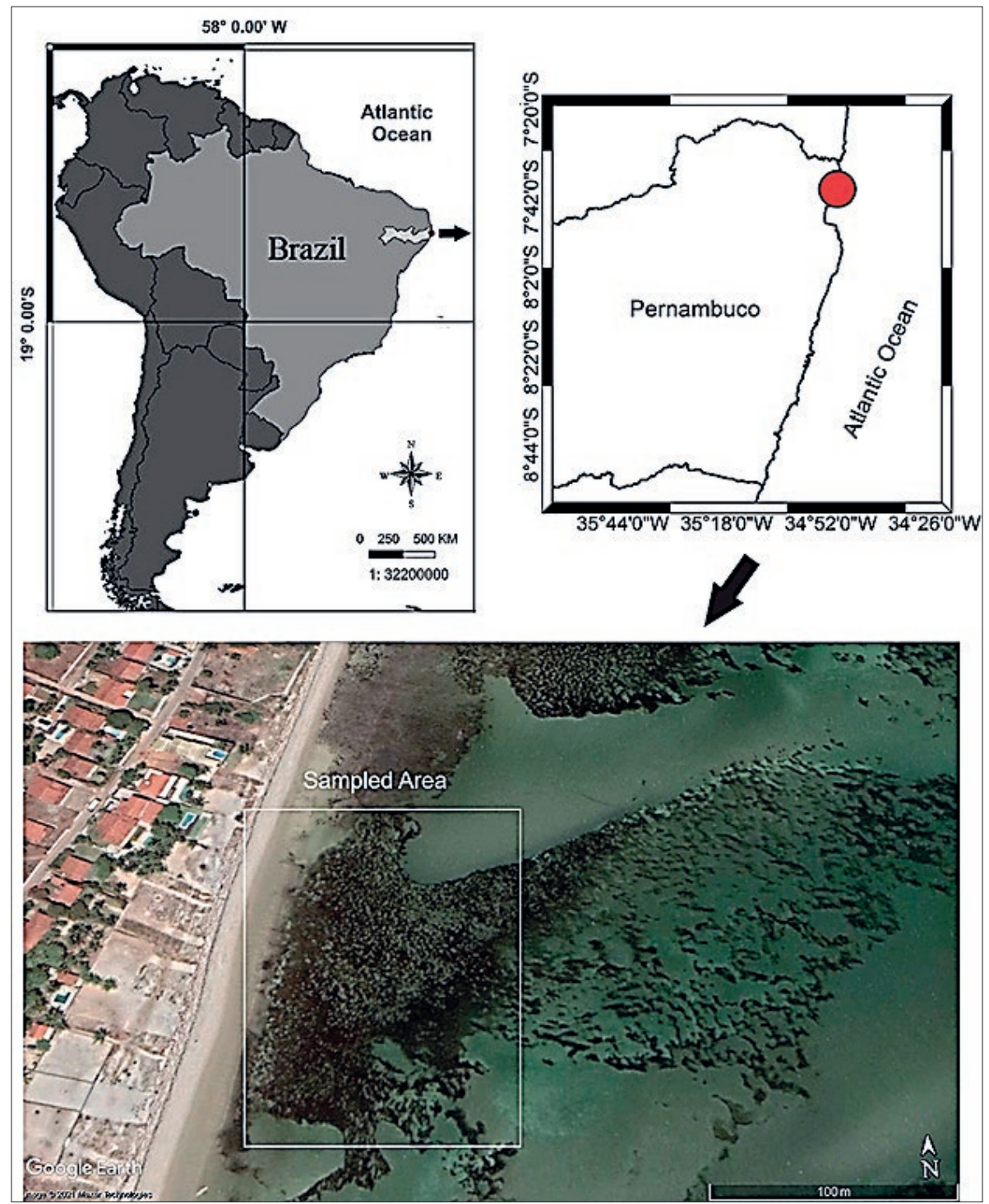

After collected, the individuals were allocated in plastic bags and stored in a styrofoam box filled with ice and forwarded to the Laboratorio de Carcinologia (Lab. Carcino) located in Museu de Oceanografia Prof. Petrônio Alves Coelho (MOUFPE) at Federal University of Pernambuco - UFPE. In laboratory, the specimens were sorted out, photographed and measured using a digital caliper $(0.01 \mathrm{~mm})$; for the crab in Carapace Length $(\mathrm{CL})$ and 
Carapace Width (CW), while for the oyster in Valve Length (VL) and Valve Width (VW). The crabs specimens were identified following Melo (1996) and the oysters according to Rios (2009), later both species were fixed in 70\% ethanol and deposited under the voucher number at MOUFPE.

Among the 10 specimens of the crab Eriphia gonagra collected in the Barra de Catuama beach, only one adult male (CL: $5.8 \mathrm{~cm}$; CW: $3.7 \mathrm{~cm}$ ) showed the association in the right side of carapace with two epibionts specimens of $O$. puelchana (left valve- VL: $1.9 \mathrm{~cm}$; VW: $1.4 \mathrm{~cm}$; VL: $1.7 \mathrm{~cm}$; VW: $1.3 \mathrm{~cm}$ ) (Voucher number: 19998). The two morphotypes of O. puelchana were observed well cemented in epibranchial and antero-lateral regions (right side) of the capace of E. gonagra (Figure 2), covering about $12,3 \%$ and 10,29 \% respectively of its carapace surface.
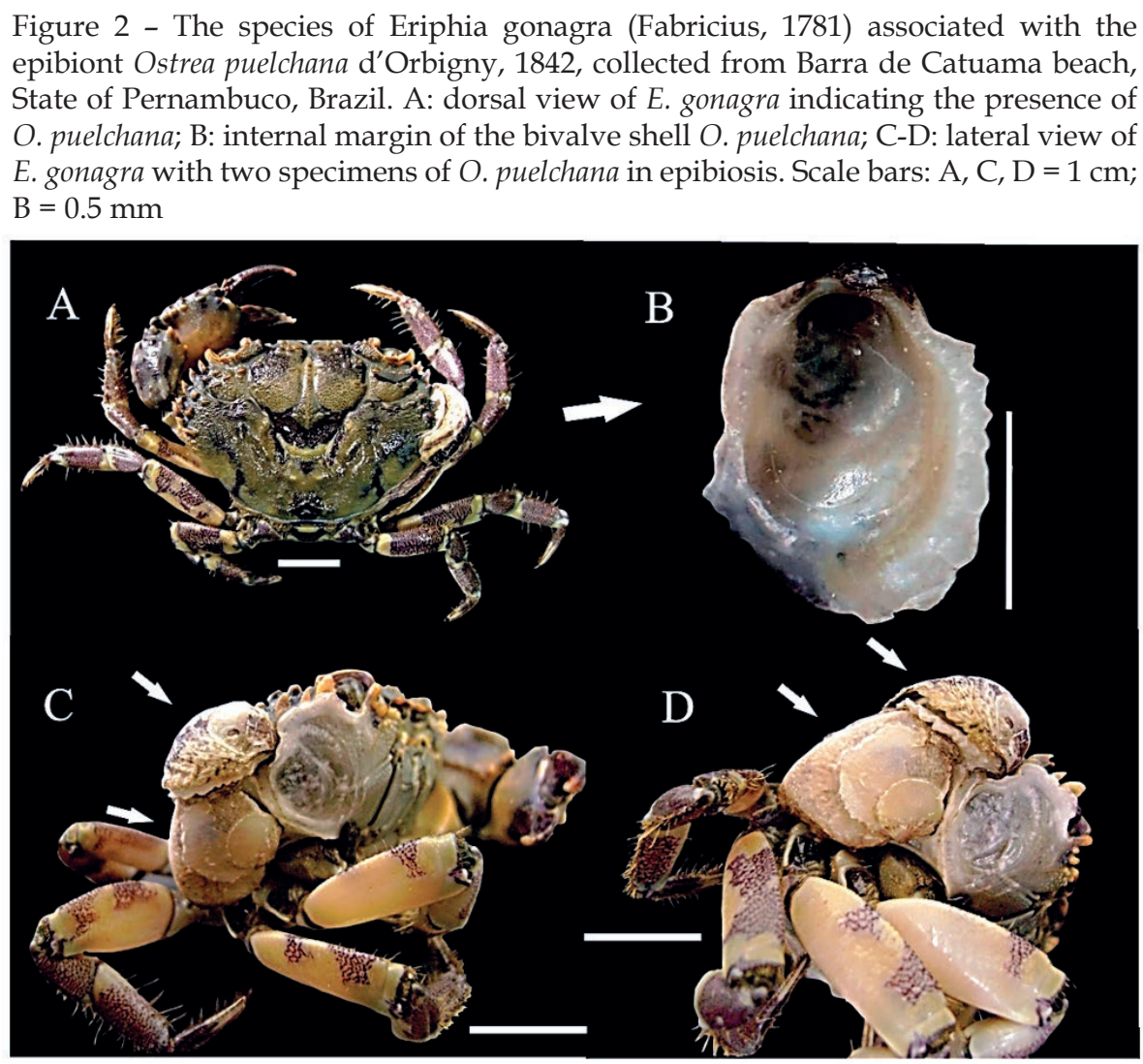

Up to date, the biological interactions between mollusks and crustaceans are widely observed in several groups, and in different ecological aspects, such as: endosymbiosis provided by pea crabs in a wider range of ostreid species (Baeza \& Thiel, 2007; Baeza et al., 2013; Martinelli-Filho; Santos \& Ribeiro, 2014; Hanke et al., 2015); ectosymbiosis as observed in the porcelain crab Porcellana sayana (Leach, 1820), which living in a wide range of gastropods (Rodríguez; Hernández \& Felder, 2005); commensalism of Blepharipoda occidentalis Randall, 1840 in the bivalve Kurtiella pedroana (Dall, 1899) (Boyko \& Mikkelsen, 2002); parasitism of Zaops ostreum (Say, 1817) in Crassostrea rhizophorae (Guilding, 1828) (Stauber, 1945; Nascimento \& Pereira, 1980) and opportunistic epibiosis performed by $O$. puelchana in the swimming crab Callinectes exasperatus (Gerstaecker, 1856) (Lima et al., 2017). 
The association provided by ostreid species adhered in mobile crustaceans as observed in the crab species C. exasperatus and in present study on E. gonagra, can be favorable to protection of epibiont (oysters), due to the advantage of the escape from predators, and additionally, this relationship favors the oyster at different food offerings in different regions for the filtration of organic matters (Lima et al., 2017). For some species of crustaceans, the occurrence of oysters in its carapaces may be favorable to extra protection against the predators (e.g. fishes and octopus), however, the crustaceans carapace act as a semi-permanent substrate for fixation of oysters (epibiont) during their development, however, during ecdysis (molting) the old carapace is discarded, with this, the epibiont can be carried to unfavorable regions by marine currents, tides or waves, and being more easily predatory by the absence of the mobility of the basibiont (Marin \& Belluga, 2005; Lima et al., 2017).

On the other hand, the occurrence of $O$. puelchana in crabs with lifestyles in intertidal zones, can negatively affect the oyster biology, specially due to long periods exposed out of water during low tide, as the case of E. gonagra which effectively live in cavities found in the upper portion on the coral reefs, being this behavior a negative point for the occurrence of epibionts in these individuals, which this characteristic favors the dehydration by exposure to the sun and air of the epibiont (Gili; Abello \& Villanueva, 1993). Epibionts adhered on the crustacean carapaces in many cases hamper the mobility of individuals, due to the extra weight and the friction of the epibiont in the water or in cavities inside the rocks, as in studies provided by Villegas, Stotz and Laudien (2005), which reported the occurrence of Semimytilus algosus (Gould, 1850) preventing the body growth and the mobility of the basibiont Emerita analoga (Stimpson, 1857) (Lima et al., 2017).

The use of the hard substrate by the ostreid species O. puelchana, especially the use of the carapaces of the brachyuran crabs for the fixation, can bean advantage for the geographic distribution of the oyster along the Brazilian and Argentine provinces, due to wide mobility provided by these individuals from different coastal regions, which allows the occurrence of this species on a wide range of hosts (basibionts) (Doldan et al., 2012; Lima et al., 2017). The associations of $O$. puelchana with many crustaceans in the natural environment can be observed in different levels of occupation, as the use of crustacean as basibiont (e.g. as observed in C. exasperatus) (Lima et al., 2017) and in E. gonagra (present study). In the same way, the species of $O$. puelchana can be host from many others decapods as observed by Martins and D'lncao (1996), which analyzed the presence of the pea crab Z. ostreum as endosymbiont of O. puelchana, while Doldan et al. (2012) reported from the same ostreid host species the endosymbiont Tumidotheres maculatus (Say, 1818). Thus, here in we observed the opportunistic fixation observed by $O$. puelchana on the new basibiont $E$. gonagra from Brazilian coast.

Acknowledgements - The authors would like to thank the Fundação de Amparo à Ciência e Tecnologia do Estado de Pernambuco (Facepe) for financing the project "Impacto do derramamento de petróleo nos ecossistemas costeiros (recifes, estuários e prados de angiospermas marinhas) no litoral de Pernambuco", process number: APQ-0628-1.08/19. Additionally, the authors would like to thank Dra. Cristina de Almeida Rocha Barreira for the support, and the anonymous reviewers for their precious comments on this paper. 


\section{REFERENCES}

Amaral, V.S. \& Simone, L.R.L. Revision of genus Crassostrea (Bivalvia: Ostreidae) of Brazil. J. Mar. Biol. Assoc. U.K., v. 94, p. 811-836, 2014.

Andrade, L.S.; Goés, J.M.; Fransozo, V.; Alves, D.F.R.; Teixeira, G.M. \& Fransozo, A. Differential habitat use by demographic groups of the redfinger rubble crab Eriphia gonagra (Fabricius, 1781). Braz. J. Biol., v. 74, n. 3, p. 597-606, 2014.

Baeza, J.A. \& Thiel, M. The mating system of symbiotic crustaceans: a conceptual model based on optimality and ecological constraints, p. 250-267, in Duffy, J.E. \& Thiel, M. (ed.). Evolutionary ecology of social and sexual systems: crustaceans as model organisms. Scholarship Online, Oxford, 2007.

Baeza, J.A.; Furlan, M.; Almeida, A.C.; Barros-Alves, S.P.; Alves, D.F.R. \& Fransozo, V. Population dynamics and reproductive traits of the ornamental crab Porcellana sayana: implications for fishery management and aquaculture. Sedao, v. 1, p. 1-12, 2013.

Boyko, C.B. \& Mikkelsen, P.M. Anatomy and biology of Mysella pedroana (Mollusca: Bivalvia: Galeommatoidea), and its commensal relationship with Blepharipoda occidentalis (Crustacea: Anomura: Albuneidae). Zoo. Anz., v. 241, p. 149-160, 2002.

Dall, W.H. Synopsis of the recent and tertiary Leptonacea of North America and the West Indies. Proc. U. S. Natl. Mus., v. 21, n. 1177, p. 873-897, 1899.

D'Orbigny, A. Mollusques, p. 1-112, in Sagra, R. (ed.). Histoire physique, politique et naturelle de I'Ile de Cuba, v. 2, parts 1-7. Paris: Bertrand, 1942.

Doldan, M.D.E.; Oehrens-Kissner, E.M.; Morsan, E.M.; Zaidman, P.C. \& Kroeck, M.A. Ostrea puelchana d'Orbigny, 1842: a new host of Tumidotheres maculatus (Say, 1818) in northern Patagonia, Argentina. Lat. Am. J. Aquat. Res., v. 40, n. 1, p. 224-228, 2012.

Emparanza, E.; Ulloa, R.; Montiel-Ramos, A. \& Molina-Ocampo, R. First record of the association of the crab Pinnaxodes gigas (Decapoda: Pinnotheridae) with the geoduck clam Panopea globosa (Bivalvia: Hiatellidae). Mar. Biod. Rec., v. 4, p. 1-4, 2011.

Fabricius, J.C. Species insectorum exhibentes eorum differentias specificas, synonyma, auctorum, loca natalia, metamorphosin adiectis observationibus, descriptionibus. Tome I. Hamburgi et Kilonii: Carol Ernest Bohnii. i-viii + 552 p., 1781.

Ferreira-Jr., A.L.; Christo, S.W. \& Absher, T.M. Primeira ocorrência de Pseudomyicola spinosus em Anadara ovalis no Complexo Estuarino de Paranaguá - Brasil. Bol. Inst. Pesca., v. 4, p. 449-456, 2015.

Gerstaecker, A. Carcinologische Beiträge. Arch. Naturg., v. 22, n. 1, p. 101-162, pls. 4-6, 1856.

Gili, J.M.; Abello, P. \& Villanueva, R. Epibionts and intermoult duration in the crab Bathynectes piperitus. Mar. Ecol. Prog. Ser., v. 98, n. 1-2, p. 107-113, 1993.

Góes, J.M. \& Fransozo, A. Sex ratio analyses in Eriphia gonagra (Crustacea, Decapoda, Xanthidae). Iheringia Ser. Zoo., v. 88, p. 151-157, 2000.

Góngora-Gómez, A.M.; Muñoz-Sevilla, N.P.; Hernández Sepúlveda, J.A. \& García-Ulloa, M. Association between the pen shell Atrina tuberculosa and the shrimp Pontonia margarita. Symbiosis, v. 66, p. 107-110, 2015. 
Gould, A.A. Descriptions of new species of shells from the United States Exploring Expedition. Proc. Boston Soc. Nat. Hist., v. 3, p. 343-348, 1850.

Guilding, L. Observations on the zoology of the Caribbean Islands. Zoological Journal, v. 3, p. 1-542, 1828.

Hanke, M.H.; Hargrove, J.M.; Alphin, T.D. \& Posey, M.H. Oyster utilization and host variation of the oyster pea crab (Zaops ostreum). J. Shellfish Res., v. 34, p. 281-287, 2015.

Hoffmeister, M. \& Martin, W. Interspecific evolution: microbial symbiosis, endosymbiosis and gene transfer. Environ. Microbiol., v. 5, p. 641-649, 2003.

Köeppen, W. Climatologia: con un estudio de lós climas de la Tierra. México: Fondo de Cultura Economica, 478 p., 1948.

Leach, W.E. Galatéadées, Galateadae (Crust.), p. 49-56, in Cuvier, F. (ed.). Dictionnaire des Sciences Naturelles, dans lequel on trait Méthodiquement des Différens étres de la Nature, considérés soit en eux-mêmes, d'après l'état actuel de nos connoissances, soit relativement a l'utilité qu'en peuvent retirer la Médecine, l'Agriculture, le Commerce et les Arts. Suivi d'une biographie des plus Célèbres Naturalistes. Ouvrage destiné aux médecins, aux agriculteurs, aux commerçans, aux artistes, aux manufacturiers, et à tous ceux qui ont intérêt à connoître les productions de la nature, leurs caractères génériques et spécifi ques, leur lieu natal, leurs propiétés et leurs usages. v. 18. F. G. Levrault et Le Normant, Strasbourg et Paris, 1820.

Lima, S.F.B.; Lucena, R.A.; Queiroz, V.; Guimarães, C.R.P. \& Breves, A. The first finding of Ostrea cf. puelchana (Bivalvia) living as epibiont on Callinectes exasperates (Decapoda). Acta Sci. Biol. Sci., v. 39, n. 1, p. 79-85, 2017.

Linnaeus, C. Systema Naturae per regna tria naturae, secundum classes, ordines, genera, species, cum characteribus, differentiis, synonymis, locis. Editio decima, reformata, v. 1, 824 p., Laurentius Salvius: Holmiae, 1758.

Macleay, W.S. On the Brachyutous Decapod Crustacea brought from the Cape by Dr. Andrew Smith, p. 53-71, in Illustrations of the zoology of South Africa, consisting chiefly of figures and descriptions of the objects of natural history collected during an expedition into the interior of South Africa, in the years 1834, 1835, and 1836; fitted out by "The Cape of Good Hope association for exploring Central Africa". Published under the Authority of the Lords Commissioners of Her Majesty's Treasury, London, 1838.

Marin, A. \& Belluga, M.D.L. Sponge coating decreases predation on the bivalve Arcanoae. J. Molluscan Stud., v. 71, n. 1, p. 1-6, 2005.

Martins, S.T.S. \& D'lncao, F. Os Pinnotheridae de Santa Catarina e Rio Grande do Sul, Brasil (Decapoda, Brachyura). Rev. Bras. Zool., v. 13, n. 1, p. 1-26, 1996.

Mantelatto, F.L.M. \& Souza-Carey, M.M. Brachyura (Crustacea, Decapoda) associated to Schizoporella unicornis (Bryozoa, Gymnolaemata) in Ubatuba bay (SP), Brazil. Braz. Arch. Biol. Technol., v. 41, n. 2, p. 1-6, 1998.

Martinelli-Filho, J.E.; Santos, R.B. \& Ribeiro, C.C. Host selection, host-use pattern and competition in Dissodactylus crinitichelis and Clypeasterophilus stebbingi (Brachyura: Pinnotheridae). Symbiosis, v. 63, p. 99-110, 2014. 
McDermott, J.J. The biology of Austinixa gorei (Manning \& Felder, 1989) (Decapoda, Brachyura, Pinnotheridae) symbiotic in the burrows of intertidal ghost shrimp (Decapoda, Thalassinidea, Callianassidae) in Miami, Florida. Crustaceana, v. 79, p. 345-361, 2006.

Melo, G.A.S. Manual de identificação dos Brachyura (Caranguejos e Siris) do Litoral Brasileiro. São Paulo: Fapesp, 604 p., 1996.

Nascimento, I.A. \& Pereira, S.A. Efeitos do caranguejo Pinnotheres ostreum em ostras Crassostrea rhizophorae. Bol. Inst. Ocean., v. 29, p. 261-265, 1980.

O'Connor, W.A. \& Newman, L.J. Halotolerance of the oyster predator, Imogine mcgrathi, a stylochid flatworm from Port Stephens, New South Wales, Australia. Hydrobiologia, v. 459, p. 157-163, 2001.

Rafinesque, C.S. Analyse de la nature ou tableau de l'univers et des corps organisés. Palerme [Palermo], Italy, 1815.

Randall, J.W. Catalogue of the Crustacea brought by Thomas Nutall and J.K. Townsend, from the West Coast of North America and the Sandwich Islands, with descriptions of such species as are apparently new, among which are included several species of different localities, previously existing in the collection of the Academy. J. Acad. Nat. Sci. Phila., v. 8, p. 106-147, 1840.

Rios, E.C. Compendium of Brazilian seashells. Porto Alegre: Evangraf, 500 p., 2009.

Rodríguez, I.T.; Hernández, G. \& Felder, D.L. Review of the western Atlantic Porcellanidae (Crustacea: Decapoda: Anomura) with new records, systematic observations, and comments on biogeography. Caribb. J. Sci., v. 41, p. 544-582, 2005.

Say, T. An account of the Crustacea of the United States. P. Acad. Nat. Sci. Phila., v. 1, n. 1, p. 57-63, 1817-1818.

Stauber, L.A. Pinnotheres ostreum, parasitic on the American Oyster, Ostrea (Gryphaea) virginica. Bio. Bull., v. 88, p. 269-291, 1945.

Stimpson, W. Notices of new species of Crustacea of western North America; being an abstract from a paper to be published in the journal of the Society. Proc. Boston Soc. Nat. Hist., v. 6, p. 84-89, 1857.

Villegas, M.J.; Stotz, W. \& Laudien, J. First record of an epibiosis between the sand crab Emerita analoga (Stimpson, 1857) (Decapoda: Hippidae) and the mussel Semimytilus algosus (Gould, 1850) (Bivalvia, Mytilidae) in southern Peru. Helgol. Mar. Res., v. 60, n. 1, p. 25-31, 2005.

Wahl, M. Ecological lever and interface ecology: epibiosis modulates the interaction between host and environment. Biofouling, v. 24, p. 427-438, 2008. 